\title{
Factors influencing crown placement of oats (Avena sativa L.)
}

\author{
R.E. RIES
}

Author is range scientist, USDA-ARS, Northern Great Plains Research Laboratory, P.O. Box 459, Mandan, N.D. 58554-0459.

\begin{abstract}
The depth of the grass crown nodes in the soil influences the susceptibility of the crown to environmental and management conditions which can affect grass establishment success and grain and forage yield levels. A controlled environment experiment was conducted to quantify the effect of planting depth $(38$ and $76 \mathrm{~mm})$, temperature $\left(25\right.$ and $\left.10^{\circ} \mathrm{C}\right)$, and light (full light $\left[900 \mu\right.$ moles $\left.\mathrm{m}^{-2} \mathrm{sec}^{-1}\right]$ and shaded at $55 \%$ full light $\left[500 \mu\right.$ moles $\left.\mathrm{m}^{-2} \mathrm{sec}^{-1}\right]$ on the elongation of oat (Avena sativa L. 'Valley') seedling internodes and the resulting final crown placement. The mesocotyl and 1st leaf internode increased in length with increased planting depth with no significant interactions. The length of the 2 nd leaf internode increased more when developed under $25^{\circ} \mathrm{C}$ temperatures than under $10^{\circ} \mathrm{C}$ (significant temperature $X$ depth interaction). However, the 2nd leaf internode elongated more under low light (55\% full light) compared to full light (significant light $X$ depth interaction). The 3rd leaf internode length was the same for the 38 and $76 \mathrm{~mm}$ planting depths when developed at $10^{\circ} \mathrm{C}$ and under $55 \%$ full light. At $10^{\circ} \mathrm{C}$-full light and $25^{\circ} \mathrm{C}-55 \%$ light, the deep planting depth resulted in increased 3rd leaf internode elongation, while at $25^{\circ} \mathrm{C}$-full light, the 3 rd leaf internode was longer when developed from $38 \mathrm{~mm}$ planting depth (significant temperature $X$ light $X$ depth interaction). The ultimate elongation of these internodes resulted in the depth and structure of the final oat crown. This study points out the importance of naming and knowing each internode since the internodes do not respond in similar manner to environmental conditions. When all factors resulting in oat crown depth location and structure are considered, one expects crowns of oat seedlings developed under $10^{\circ} \mathrm{C}$ to contain 4 nodes somewhat separated and crowns containing only 3 nodes more widely separated under temperature conditions of $25^{\circ} \mathrm{C}$. The most compact crown developed under reduced light conditions, from $38 \mathrm{~mm}$ planting depth, and a temperature of $10^{\circ} \mathrm{C}$. This information concerning the morphology of crown structure and location is expected to be similar for annual and perennial forage grasses with an oat type seedling morphology when seeded at similar temperatures, light intensities, and planting depths.
\end{abstract}

The author would like to thank Mr. Curtis A. Klein for technical assistance. The statistical support of Dr. Gary V. Richardson, Statistician, USDA-ARS is gratefully acknowledged. A special thank you to Dr. Michael S. McMullen, professor, North Dakota State University, for providing the pure line oat seed used in this experiment.

This article is a contribution from USDA-ARS, Mandan, North Dakota. USDA, ARS, Northern Plains Area, is an equal opportunity/affirmative action employer and all agency services are available without discrimination.

Manuscript accepted 7 Jun. 1998.

\section{Resumen}

La profundidad del suelo a la cual se encuentran ubicados los nudos de la corona de los zacates influye en la susceptibilidad de la corona a condiciones ambientales y de manejo que pueden afectar el éxito del establecimiento de los zacates y los niveles de producción de forraje y grano. Se condujó un experimento en ambiente controlado para cuantificar los efectos de la profundidad de siembra $(38$ y $76 \mathrm{~mm})$, temperatura $\left(25\right.$ y $\left.10^{\circ} \mathrm{C}\right)$ y luz [iluminación total $\left(900 \&\right.$ moles $\mathrm{m}^{-1}$ $\left.\mathrm{sec}^{-1}\right)$ y sombreado, $55 \%$ de la iluminación total (500 \& moles $\left.\mathrm{m}^{-1} \mathrm{sec}^{-1}\right)$ ] en la elongación de los internudos de plántulas de avena (Avena sativa L. 'Valley') y la ubicación final de la corona. La longitud del mesocotilo y el internudo de la primera hoja se incrementaron al aumenter la profundida de siembra, sin haber interacciones significativas. La longitud del internudo de la segunda hoja fue mayor a $25^{\circ} \mathrm{C}$ que a $10^{\circ} \mathrm{C}$ (la interacción temperatura $\mathrm{x}$ profundidad fue significativa). Sin embargo, el internudo de la segunda hoja se elongó mas bajo sombreado (55\% de la iluminación total) comparado con la iluminación total (interacción significativa entre luz $X$ profundidad) Cuando las plántulas crecieron a $55 \%$ de la iluminación total $y 1^{\circ} \mathrm{C}$, la longitud del internudo de la tercer hoja fue igual a ambas profundidades de siembra. A $10^{\circ} \mathrm{C}$-iluminación total y $25^{\circ} \mathrm{C}-55$ de la iluminación total, la mayor profundidad de siembra resultó en un incremento de la elongación del internudo de la tercer hoja, mientras que a $25^{\circ} \mathrm{C}$ iluminación total el internudo de la tercer hoja fue mas largo a la profundidad de $38 \mathrm{~mm}$ (interacción significativa entre temperatura $x$ luz $x$ profundida de siembra). La elongación final de estos intrenudos definió la profundida y estructura final de la corona de avena. Este estudio remarca la importancia de nombrar y conocer cada internudo ya que estos no responden de manera similar a las condiciones ambientales. Cuando se consideran todos los factores que dan como resultado la profundidad, localización y estructura de la corona, se esperaría que las coronas de plántulas de avena desarrolladas a $10^{\circ} \mathrm{C}$ tuvieran solo 4 internudos algo separados $\mathrm{y}$ las coronas desarrolladas a $25^{\circ} \mathrm{C}$ tendrían 3 nudos mucho más separados. La corona más compacta fue desarrollada bajo condiciones de poca luz a $38 \mathrm{~mm}$ de profundidad de siembra y temperatura de $10^{\circ} \mathrm{C}$. Se espera que esta información respecto a la estructura de la morfología de la corona y su localización sea similar para zacates perennes y anuales con un tipo de morfología de plántula similar a la avena y sembrados a temperaturas, condiciones de luz y profundidades de siembra similares a las de este estudio.

Key Words: crown depth, mesocotyl, leaf internodes, light, temperature, planting depth, interaction 
The location of the crown of an annual or perennial grass is important to the establishment, survival, and production of the grass plant. The crown of a grass plant has been defined as the location where 2 or more stem nodes remain close together (Hyder 1974). The depth of the crown nodes in the soil influences the susceptibility of the crown to environmental and management conditions around it. Poulos and Allan (1989) found winter wheat plants with deeper crown placement were less likely to winter kill. Forage grass plants with deeper set crowns are more likely to establish adventitious roots and less likely to be killed by close grazing of fire (Hyder 1974).

Light, temperature, and planting depth have been reported as primary factors affecting crown placement for wheat, barley, and other grasses (Taylor and McCall 1936, Webb and Stephens 1936, Ferguson and Boatwright 1968, Martin et al. 1988, and Ries and Hofmann 1995). However, because of interactions and inconsistent crown depths in response to different light and temperature levels, questions still remain. Oat is known to develop its crown at the coleoptilar or various leaf nodes by elongation of various internodes along the seedling stem (Avery 1930). Ries and Hofmann (1991) reported that smooth bromegrass (Bromus inermis Leyss.) was an oat type seedling and this type seedling provided for the most variable emergence and crown placement. Oat seedling emergence, crown placement, and morphological structures are similar to other important forage grass (genera such as Bromus, Lolium, and Elymus.) Oat was selected for this study because its larger seeds and morphological structures are more easily observed. The purpose of our study was to quantify the effect of planting depth, temperature, and light on the elongation of oat seedling internodes and the resulting final crown placement.

\section{Materials and Methods}

This controlled environment experiment was conducted in 2 growth chambers with high intensity sodium and multivapor lamps at the Northern Great Plains Research Laboratory, Mandan, N.D. These lamps simulate sunlight and provide wavelengths across the visible spectrum. At $2,000 \mu \mathrm{mol} \mathrm{m}{ }^{-2}$ $\mathrm{sec}^{-1}$, the maximum irradiation is $4,500-8,000 \mathrm{~m} \mathrm{~W} \mathrm{~m}^{-2} \mathrm{~nm}^{-2}$ at wavelengths of $500-625 \mathrm{~nm}$. The complete experiment was conducted twice. One experiment included 2 cycles: Cycle 1growth chamber \#1 was set at $25^{\circ} \mathrm{C}$ with full light $\left(900 \mu\right.$ moles $\left.\mathrm{m}^{-2} \mathrm{sec}^{-1}\right)$ and growth chamber \#2 was set at $10^{\circ} \mathrm{C}$ with $55 \%$ full light $(500 \mu$ moles $\left.\mathrm{m}^{-2} \mathrm{sec}^{-1}\right)$. Cycle 2-growth chamber \#1 was set at $10^{\circ} \mathrm{C}$ with full light and growth chamber $\# 2$ was set at $25^{\circ} \mathrm{C}$ with $55 \%$ full light. A relative humidity of about $55-60 \%$ was maintained in both growth chambers. Since temperature and light were the environmental factors under study, they were kept constant 24 hours a day for the duration of each experiment. Light and temperature were measured in the growth chambers during the study. Light measured at the soil level in the cylinders was $786(\mathrm{se}=14)$ and $432(\mathrm{se}=9) \mu$ moles $\mathrm{m}^{-2} \mathrm{sec}^{-1}$ for the full light and $55 \%$ full light treatments. Chamber air temperatures were very similar to the programmed temperatures and were $23.4^{\circ}(\mathrm{se}=1.0)$ and $9.9^{\circ}(\mathrm{se}=0.9) \mathrm{C}$ in the 2 chambers. Soil temperatures at the 38 and $76 \mathrm{~mm}$ planting depths were measured with thermocouples.

Black PVC cyclinders ( $52 \mathrm{~mm}$ diameter and $203 \mathrm{~mm}$ long) were packed with a Lihen soil (sandy, mixed Entic Haploborolls) to a bulk density of 1.4 $\mathrm{g} \mathrm{cm}^{-3}$ to a 38 or $76 \mathrm{~mm}$ planting depth. For each cycle, 3 cylinders were used to evaluate emergence parameters and 6 cylinders were used to evaluate parameters at 35 days. Four oat seeds were planted in each cylinder and covered with the same soil packed to the same bulk density to within $10 \mathrm{~mm}$ of the top of the cylinder. Oat is largely self-pollinated, so 'Valley', a pure line of oat seed, was used in this study to limit genetic variability between oat seedlings. After seeding, each cylinder was watered with half-strength Hoagland's nutrient solution (100 ppm N) (Hoagland and Arnon 1950) to field capacity (22\% soil water by volume). Cylinders were brought to field capaci- ty with tap water the second and third day after seeding and then maintained at $50 \%$ available water (14\% soil water by volume). Nutrient solution was added once each week and the cylinders were watered to field capacity every 10 days. Soil water was measured in cylinders harvested at emergence and 35 days. Three extra cylinders per planting depth were filled, seeded, and watered and destructively sampled to monitor soil water at 14 , 21 , and 28 days after initial watering.

Oat seedlings were destructively sampled from 3 cylinders at emergence. The number of germinated oat seeds per cylinder was also noted. The time after seeding that the first seedling emerged was noted and recorded to the nearest quarter of a day. This seedling was washed from the soil and measured. Measurements of the first emerged oat seedling included vertical planting depth, vertical length of the mesocotyl, and vertical length of the coleoptile.

Six cylinders were visually observed and the first emerged oat seedling in each cylinder was marked. The total number of oat seedlings emerging from each cylinder was recorded. When emergence was complete, all oat seedlings except for the first to emerge were thinned from the cylinders. Oat seedlings from these 6 cylinders were destructively sampled 35 days after seeding and the number of primary roots, vertical planting depth, vertical length of the mesocotyl and developed leaf internodes, and the location of the plant crown and associated nodes were recorded.

Statistical design of this study was a split-split plot with 3 replicates at emergence and 6 replicates at 35 days. Main plots consisted of the 2 runs of the experiment, the subplots consisted of a 2 temperature $\times 2$ light factorial with sub subplots being planting depths. The experiment $X$ temperature $X$ light interaction was tested for significance by error a. If significant, this term was used to test the significance of the main effects; experiment, temperature, light, and temperature $\times$ light interaction. The secondary experiment $X$ depth $X$ temperature $X$ light interaction was tested by error $b$ and if 
significant, was used to test the significance of the secondary effects of planting depth, planting depth $\times$ temperature, planting depth $\times$ light, and planting depth $X$ temperature $X$ light interactions (SAS Institute 1990).

\section{Results}

\section{Cylinder Conditions}

Soil water in the cylinders was stable and quite uniform in all temperature and light treatments from 14-35 days after the initial watering of each cylinder. The water content within each cylinder was $2.3(\mathrm{se}=0.1)$ and 2.5 (se $=0.1) \mathrm{mm}$ of water, respective$1 \mathrm{y}$, in the 19-38 and $57-76 \mathrm{~mm}$ soil depth zones. Soil drying within the cylinders between watering progressed from the soil surface to deeper depths similar to what occurs in field profiles. Soil temperatures in the cylinders were $24.3^{\circ}$ (se $=1.0$ and $11.2^{\circ}(\mathrm{se}=1.9) \mathrm{C}$ at the $38 \mathrm{~mm}$ planting depth and $24.0^{\circ}(\mathrm{se}=0.5)$ and $11.1^{\circ}$ ( $\mathrm{se}=1.3$ ) $\mathrm{C}$ at the $76 \mathrm{~mm}$ planting depth. These elevated temperatures at the $38 \mathrm{~mm}$ planting depth and minor cooling at the deeper planting depth is similar to the temperature gradient in field soil profiles.

\section{At Emergence}

Measured planting depths averaged $38.5(\mathrm{se}=0.2)$ and $76.0(\mathrm{se}=0.2) \mathrm{mm}$ for all cylinders harvested. Seed germination was $100 \%$ with $75 \%$ emergence of the oat seeds planted in all cylinders regardless of planting depth, temperature, or light. The time averaged over both planting depths for oat seedlings to emerge was significantly faster at $25^{\circ} \mathrm{C}$ (4.25 days) compared to $10^{\circ} \mathrm{C}(9.25$ days $)(\mathrm{P}>\mathrm{F}=0.0076)$. At emergence, the mesocotyl length of oat seedlings averaged over both planting depths were numerically shorter under $25^{\circ} \mathrm{C}(37 \mathrm{~mm})$ compared to $10^{\circ} \mathrm{C}(42 \mathrm{~mm})(\mathrm{P}>\mathrm{F}=0.1071)$. Oat seedlings emerged 1.75 days faster when seeded at the $38 \mathrm{~mm}$ (5.75 days) than the $76 \mathrm{~mm}$ (7.50 days) depth (P > $F=0.0006)$. Mesocotyl length was greater with deeper planting, $52 \mathrm{~mm}$ at the $76 \mathrm{~mm}$ depth and $28 \mathrm{~mm}$ at the 38 $\mathrm{mm}$ planting depth $(\mathrm{P}>\mathrm{F}=0.0001)$. No significant interactions were observed for these factors.

Coleoptile length exhibited a significant plant depth $X$ temperature interaction (Fig. 1). Temperature did not affect coleoptile length at shallow planting depth. At the deeper planting depth, coleoptile length increased as temperature increased.

\section{At 35 Days}

All seedlings, regardless of planting depth, temperature, or light, averaged 4 primary roots per oat seedling harvested. Mesocotyl and 1st leaf internode lengths of oat seedlings were significantly related only to planting depth. The mesocotyls were $28 \mathrm{~mm}$ when planted at $38 \mathrm{~mm}$ and $52 \mathrm{~mm}$ when planted at $76 \mathrm{~mm}(\mathrm{P}>\mathrm{F}=$ $0.0001)$. First leaf internodes were 1 $\mathrm{mm}$ long when planted at $38 \mathrm{~mm}$ and $9 \mathrm{~mm}$ long when planted at $76 \mathrm{~mm}(\mathrm{P}$ $>\mathrm{F}=0.0020)$. No significant interactions were observed for these 2 internodes. The length of the mesocotyl in relationship to planting depth was the same at emergence and 35 days indicating that the mesocotyl elongation was complete at emergence.

The length of the 2nd leaf internode increased more when developed under $25^{\circ} \mathrm{C}$ temperatures than under $10^{\circ} \mathrm{C}$ (significant temperature $X$ depth inter- action) (Fig. 2). However, the 2nd leaf internode elongated more under low light (55\% full light) compared to full light (significant light $X$ depth interaction) (Fig. 3). Note that $\mathrm{n}$ is not the same for all treatments because of nonemergence, deaths, or nondevelopment of structure being evaluated.

The 3rd leaf internode length at $10^{\circ} \mathrm{C}-55 \%$ light was the same for the 38 and $76 \mathrm{~mm}$ planting depth. At $10^{\circ} \mathrm{C}$ full light and $25^{\circ} \mathrm{C}-55 \%$ light, the deep planting depth resulted in increased 3rd leaf internode length, while, at $25^{\circ} \mathrm{C}$ full light, the 3rd leaf internode was longer when developed from $38 \mathrm{~mm}$ depth (significat temperature $X$ light $X$ depth interaction) (Fig. 4).

The significant main effects and interactions that result in the final crown placement for oat seedlings in this study are summarized in Fig. 5. Under $25^{\circ} \mathrm{C}$ temperatures, the 3rd leaf node was above the soil surface for both light intensities and planting depths. Under $10^{\circ} \mathrm{C}$ temperatures, the 3rd leaf node was always below the soil surface. Even though the nodes of the oat seedlings are separated by several $\mathrm{mm}$, the oat crowns developed under $25^{\circ} \mathrm{C}$ temperatures had only 3 nodes in the crown, while, oat seedlings developed under $10^{\circ} \mathrm{C}$ had 4 nodes per crown.

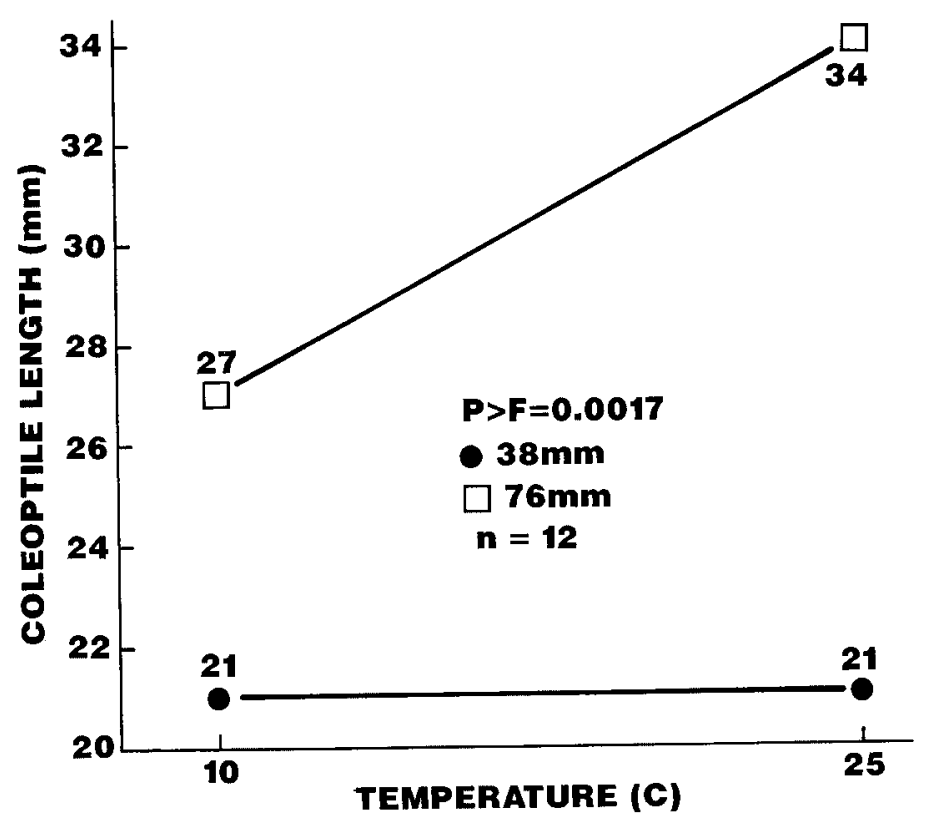

Fig. 1. Significant temperature $\times$ planting depth interaction for oat seedling coleoptile elongation at emergence. 


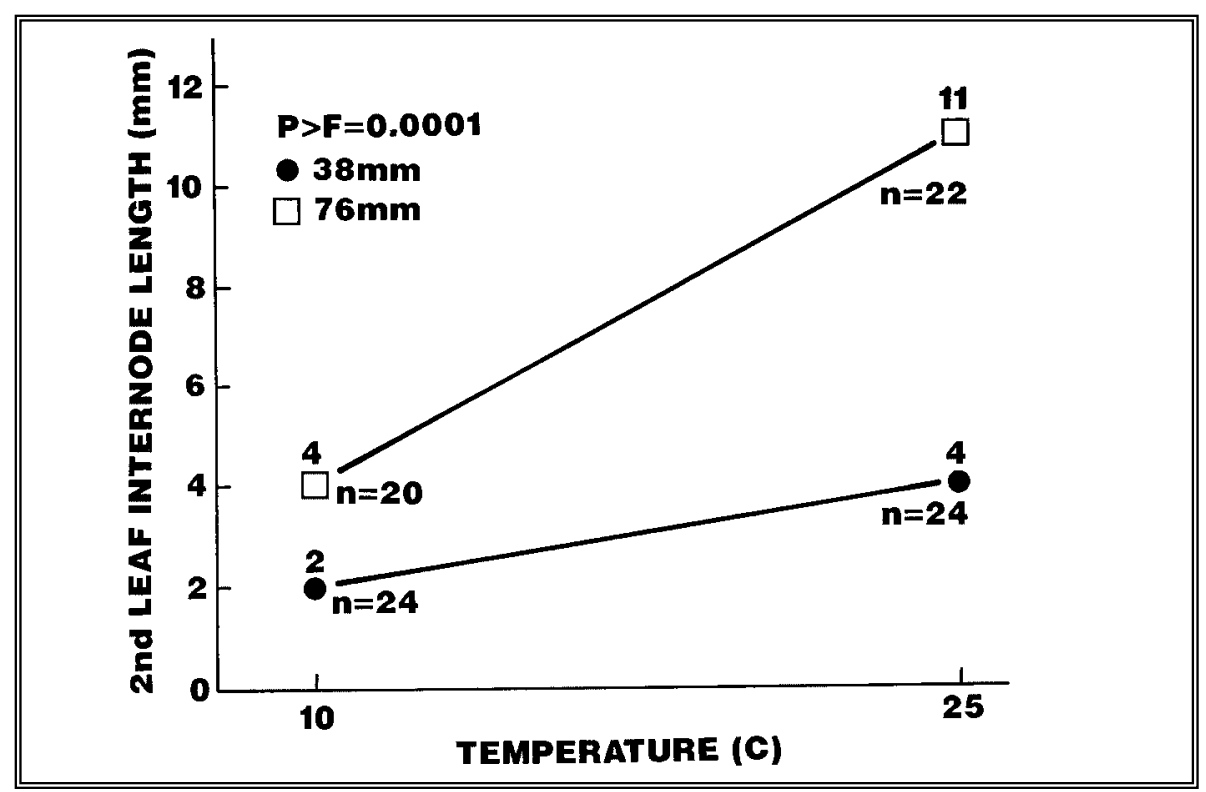

Fig. 2. First significant 2-way interaction of temperature $\times$ planting depth for oat seedling 2nd leaf internode elongation at 35 days after seeding.

\section{Discussion}

Corn, oats, and wheat were considered examples of the classical morphological types of grass seedlings (Van Tieghem 1897). Corn emerged with considerable elongation of the mesocotyl and minimal elongation of the coleoptile, oats emerged from th esoil with moderate elongation of both the mesocotyl and coleoptile, and wheat emerged by elongation of only the coleoptile. We choose oats for this study because it has larger seeds and morphological structures than the perennial grasses that have similar mechanism of emergence and crown placement. Other genera of grasses with seedling development and structure similar to oat seedlings are Bromus, Lolium, Briza, Milium, Elymus, Hystrix, and Descampsia (Hoshikawa 1969). Bromus, Lolium, and Elymus are the genera that contain many annual and perennial forage grasses important to pasture and range management.

Results of this study show that the mesocotyl and the 1st leaf internode elongation, the 2 deepest placed oat seedling structures, were greater when planted at deeper planting depths. The 2nd and 3rd leaf internodes, the most shallow oat seedling structures, did not elongate consistently in relation- ognized that the subcrown internode in wheat sometimes included elongation of several internodes above the coleoptilar node. Ries and Hofmann (1991) suggest that the identification and name of each internode that elongates in grass seedlings is important to understanding grass plant establishment and crown location. The importance of knowing which internodes are elongating is demonstrated in this study because the internodes, mesocotyl (often called the first internode), and subsequent leaf internodes did not respond in a similar manner to temperature, light, and planting depth conditions.

This study was started using a high temperature of $30^{\circ} \mathrm{C}$. No oat seedlings emerged from the $76 \mathrm{~mm}$ planting depth and, compared with lower temperatures, we observed reduced elongation of the mesocotyl in the oat seedling that did not emerge. Weaich et al. (1996) reported a significant reduction in the mesocotyl length for maize shoots at temperatures greater than $40^{\circ} \mathrm{C}$. Radford and Key (1993) reported poor field emergence of oats at temperatures of $30^{\circ} \mathrm{C}$ and above. They attributed this poor emergence to cessation of the germination process and possibly reduced seedling elonga-

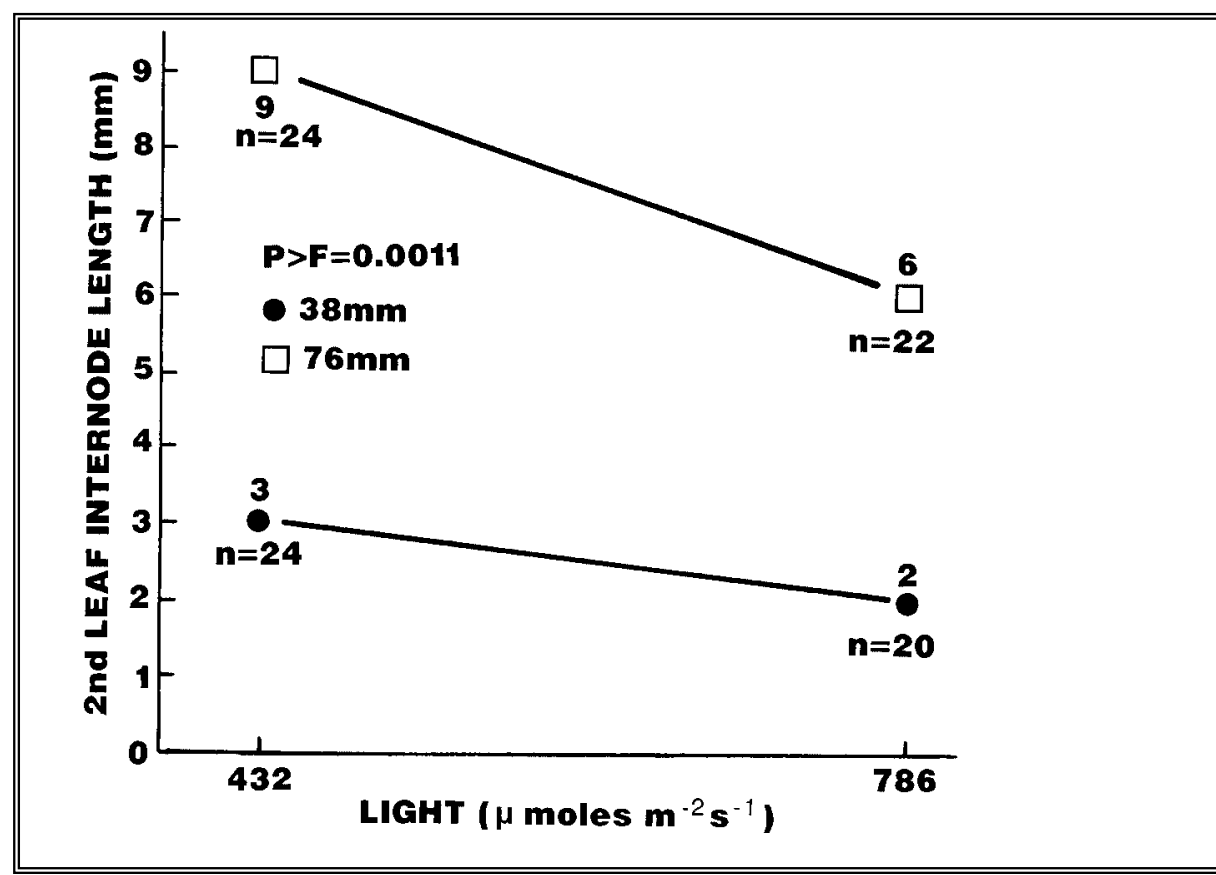

Fig. 3. Second significant 2-way interaction of light $\times$ planting depth for oat seedling 2 nd leaf internode elongation at 35 days after seeding. 


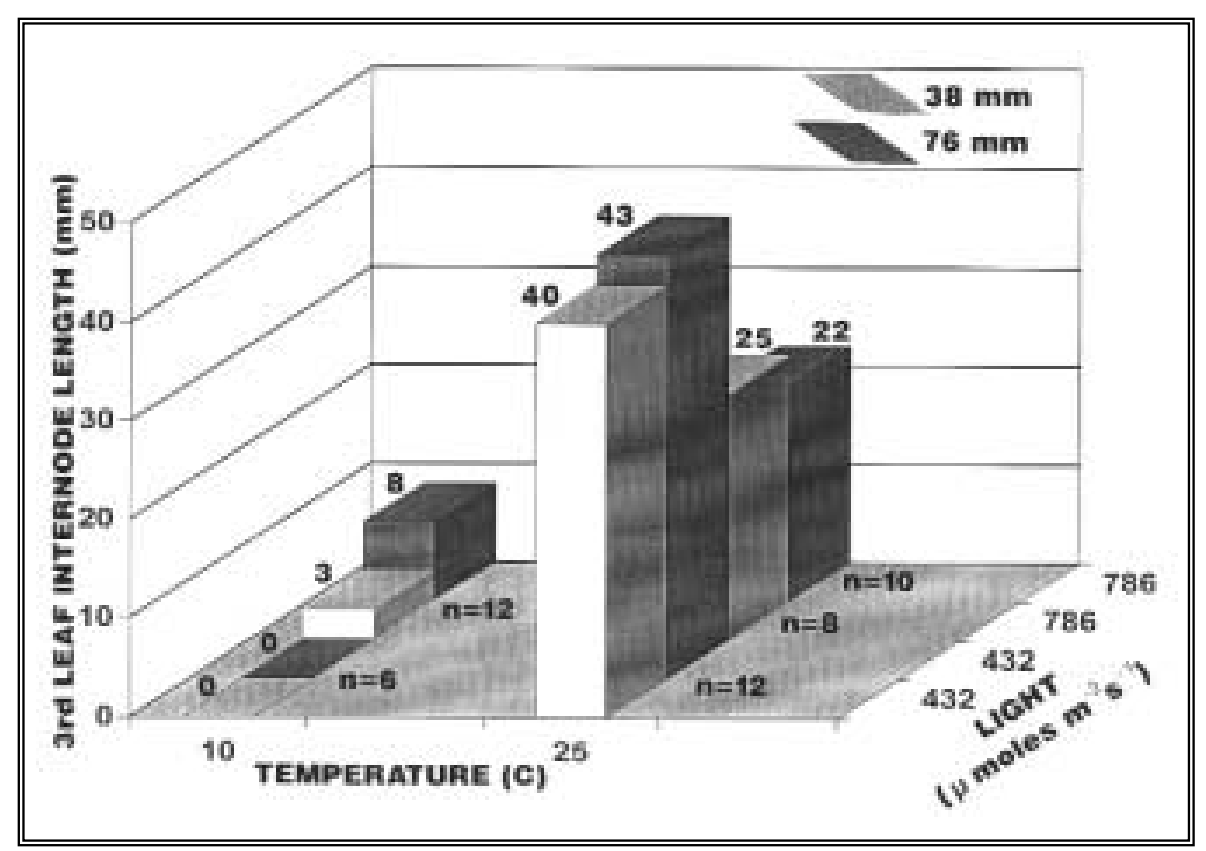

Fig. 4. Significant 3-way interaction of temperature $\times$ light $\times$ planting depth for oat seedling 3rd leaf internode elongation at 35 days after seeding.

tion. However, they attributed a reduction in coleoptile + mesocotyl elongation when temperatures increased above $20^{\circ} \mathrm{C}$ to reduced coleoptile rather than mesocotyl length. We found that the mesocotyl length of our oat seedlings decreased with increased temperature from $10^{\circ}$ to $25^{\circ} \mathrm{C}(\mathrm{P}>\mathrm{F}$ $=0.1071)$. We further found that the length of our oat seedling coleoptiles responded to a significant temperature $X$ planting depth interaction.

Depending on the depth of planting, soil temperatures, and light conditions, a crown with a different location and structure will develop for oat seedlings. Planting depth is important to the elongation of the mesocotyl and 1st leaf internode with no significant interaction with other environmental factors. The length of the oat coleoptile was influenced by changes in temperatures and planting depth. Longer coleoptiles resulted from deeper planting depths at $25^{\circ} \mathrm{C}$. The elongation of the 2 nd leaf internode was related to 2 significant interactions; temperature $X$ planting depth and light $X$ planting depth. Elongation of the 3rd leaf internode was related to a significant 3 -way interaction of temperature $X$ light $\times$ planting depth. depth conditions in order of their depth in the soil. The length of the mesocotyl and $1^{\text {st }}$ leaf internode, the deepest structures, increased with depth of planting and had no significant interactions. The coleoptile length, a structure that approaches or exceeds the soil surface at maturity, varied with temperature and planting depth. The $2^{\text {nd }}$ leaf internode which is closer to the soil surface varied in length by significant temperature $X$ planting depth and light $X$ planting depth interactions. The $3^{\text {rd }}$ leaf internode, the internode closest to or above the soil surface elongated in relationship to a 3-way interaction of temperature $\times$ light $\times$ planting depth. It appears that the sensory portion of these structures that result in elongation rate or termination of elongation in response to surface temperature or light (intensity and/or quality) is influenced differently depending on the location of the structures below the soil surface.

When all factors influencing oat crown depth location and structure are considered (Fig. 5), crowns of oat

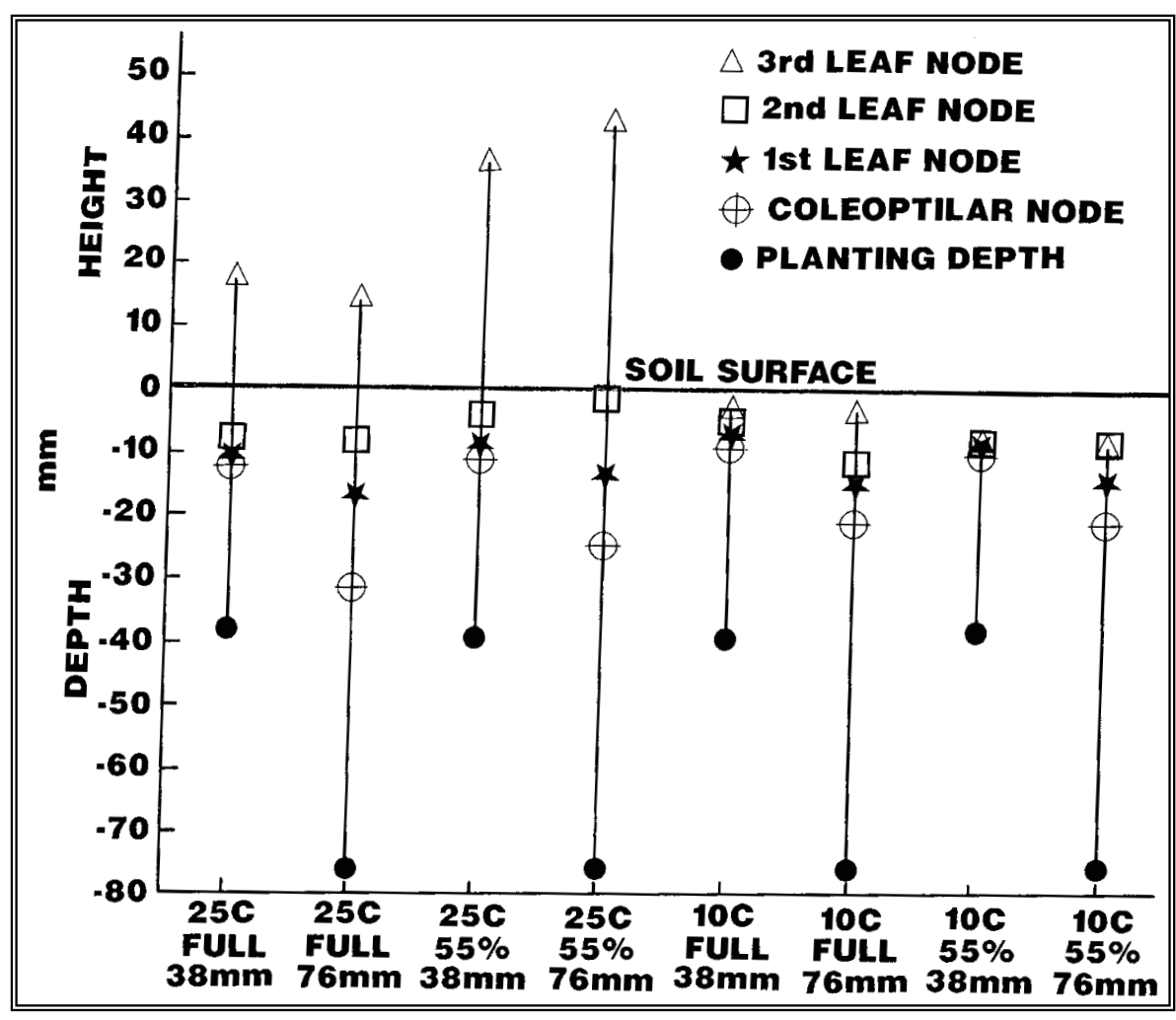

Fig. 5. Diagram that summarizes crown location 35 days after seeding of oat seedlings grown under different temperatures, light intensities, and planting depths. 
seedlings developed under $10^{\circ} \mathrm{C}$ contained 4 nodes somewhat separated and crowns developed under $25^{\circ} \mathrm{C}$ contained only 3 nodes that are more widely separated. The most compact crown developed under reduced light conditions, from a $38 \mathrm{~mm}$ planting depth, and a temperature of $10^{\circ} \mathrm{C}$. This information provides an idea of what kind of crown location and structure can be expected for other annual and perennial grasses with an oat type seedling development and morphology. More research is needed to document the importance of the different crown depths and structures to forage and grain yield for the oat type annual and perennial grasses.

\section{Literature Cited}

Avery, G.S., Jr. 1930. Comparative anatomy and morphology of embryos and seedlings of maize, oats, and wheat. Bot. Gaz. 89:1-39.

Ferguson, H. and G.O. Boatwright. 1968. Effects of environmental factors on the development of the crown node and adventitious roots of winter wheat (Triticum aestivum). Agron. J. 60:258-260.
Hoagland, D.R. and D.I. Arnon. 1950. The water-culture method for growing plants without soil. California Agr. Exp. Sta. Cir. 347, 39 pp.

Hoshikawa, K. 1969. Underground organs of the seedlings and the systematics of Gramineae. Bot. Gaz. 130:192-203.

Hyder, D.N. 1974. Morphogenesis and management of perennial grasses in the United States. pp. 89-98. In: Plant morphogenesis as a basis for scientific management of range resources. Proc. Workshop of the U.S./Australian Rangeland Panel (29 Mar-5 Apr. 1971, Berkeley Calif.) USDA Misc. Pub. 1271.

Martin, J.M., C.W. Smith, and A.H. Ferguson. 1988. Subcrown internode length of spring wheat and barley as influenced by light and soil temperature. Agron. J. 80:571-573.

Poulos, J.M. and R.E. Allan. 1989. Genetic and environmental considerations for evaluating crown position of wheat. Theor. Appl. Genet. 78:359-364.

Radford, B.J. and A.J. Key. 1993. Temperature affects germination, mesocotyl length and coleoptile length of oat genotypes. Aust. J. Agr. Res. 44:677-688.
Ries, R.E. and L. Hofmann. 1991. Research observations: standardized terminology for structures resulting in emergence and crown placement of 3 perennial grasses. J. Range Manage. 44:404-407.

Ries, R.E. and L. Hofmann. 1995. Grass seedling morphology when planted at different depths. J. Range Manage. 48:218-223.

SAS Institute. 1990. SAS User's Guide, Version 6, Vol. 1\&2. Cary, N.C.

Taylor, J.W. and M.A. McCall. 1936. Influence of temperature and other factors on the morphology of the wheat seedling. J. Agr. Res. 52:557-568.

Van Tieghem, P. 1897. Morphologie de lembryon et de la plantule chez les Graminees et les Cyperocees. Ann. Sci. Nat. Bot. VIII. 3:259-309. (cf. Avery, 1930).

Weaich, K., K.L. Bristow, and A. Cass. 1996. Modeling preemergence maize shoot growth: II high temperature stress conditions. Agron. J. 88:398-403.

Webb, R.B. and D.E. Stephens. 1936. Crown and root development in wheat varieties. J. Agr. Res. 52:569-583. 